\title{
Socio-economic Correlates of Attitude of Youth of Fishing Communities towards Fishing Occupation in Kashmir Valley
}

\author{
Ishrat Aishi $^{*}$, Rizwana Malik ${ }^{1}$, Sajad H. Baba ${ }^{1}$, Bilal A. Bhat ${ }^{1}$, \\ Shazia Tariq ${ }^{1}$, T.A. Rather ${ }^{2}$ and M.A. Islam $^{2}$ \\ ${ }^{1}$ Division of Social Sciences, Faculty of Fisheries, Sher-e-Kashmir University of Agricultural \\ Sciences and Technology-Kashmir, Rangil, Ganderbal, J\&K, India \\ ${ }^{2}$ Faculty of Forestry, Sher-e-Kashmir University of Agricultural Sciences and Technology- \\ Kashmir, Rangil, Ganderbal, J\&K, India \\ *Corresponding author
}

\section{A B S T R A C T}

\begin{abstract}
Youths constitute a formidable force in the agricultural production process, constituting a sizeable proportion of the workforce especially in the rural areas. The study was conducted to find out the relationship between socio-economic characteristics of youth of fisher communities and their attitude towards fishing occupation district Bandipora of Jammu and Kashmir. Simple random sampling technique was adopted to select 120 respondents from the 4 selected villages. Data were collected using structured pretested interview schedule among the respondents. Correlation analysis was carried out to analyze the relationship between socio-economic attributes and the attitude of youth towards fishing occupation using SPSS software. Results revealed that among the socio-economic characteristics age, marital status, educational qualification, family type, household earners and investment on fishing inputs had exhibited negative and significant correlation $(\mathrm{r}=$ 0.376 to $-0.787, p=0.05$ ) with the attitude of youth towards fishing occupation while the variables like active fishing days and income through fishing in summer have shown positively significant correlation ( $r=0.183$ to $0.845, \mathrm{p}=0.05)$. Other characteristics such as residential background, house type, number of dependents, household expenditure, income through fishing in winter, marketing channels and opted alternate source had nonsignificant correlation $(r=-0.004$ to $0.173, p=0.05)$ with the attitude of youths towards fishing occupation. The need to provide social amenities and infrastructures that will make the youths live and work in the rural areas is emphasized. The findings will help extension policy makers to frame appropriate training programmes for educating youth regarding opportunities in fishery and allied sectors.
\end{abstract}

\section{Introduction}

Attitude can be defined as "a predisposition or a tendency to respond positively or negatively towards a certain idea, object, person or situation (Likert, 1932). Attitude and opinion surveys are widely used to understand why people make decisions, and behave in certain ways (Aphunu and Akpobasa, 2010). Attitude has been defined as a "mental or neutral state of readiness" structured through experience which has a positive impact on a person's reaction or behaviour towards a phenomenon (Brousmiche et al., 2016). Attitude emerges 
from a combination of different factors such as the individual's "personality, beliefs, values behaviours and motivations" (Islam et al., 2015a). Attitude helps us define how we see situations as well as define how we act towards the situation or object. For instance, a person's attitude towards new innovation is based on his or her previous experience, values and personality. Attitude underpins individuals' predisposition to adopt an innovation. Surveys elicit respondents' beliefs about important issues that might influence their behavior and actions (that may or may not be directly observable) (Nataraju et al., 2019). Attitudes play a major role in acceptance of fishing occupation actions by the fishing occupation and policy makers in particular.

Examining people's attitudes is important for formulating policies and management actions, and generating public awareness (Onima et al., 2017). Youth are the strongest segment of the society of the society. The World Bank (2001) noted that majority of the world population consists of young people, three quarters of them living in the rural areas. The overall development of a country depends on their regimented, active and skilled youth power (Gangwar and Kameswari, 2016). Development of youth thus determines the development of community and country as a whole (Movahedi et al., 2013). Youth being active citizens and creative digital innovators in their community are eager to positively contribute to the sustainable development (Pakhmode et al., 2018). Therefore, to bring rapid progress for a country, this section of the population need to be harnessed, motivated, skilled and streamlined properly (Eyinade and Akharume, 2018). Youth unemployment is one of the major problems affecting developing countries. One of the reasons behind this problem is the lack of basic education. UNICEF reported that youth unemployment is compounded by the fact that large portion of the population in developing countries tends to be youth (Kharmudai et al., 2018). It is disturbing to note that youth are losing interest and confidence in agriculture and allied activities; hence they are not willingly involved in agricultural and allied activities. Most of the rural youth do not foresee a prosperous future for themselves in the fishing sector mainly because of the lack of profitability and also the lack of infrastructure and facilities in rural areas (Parmar et al., 2015). The young generation perceives fishing as an occupation for the old, illiterate and poor rural people (Njeru et al., 2015). Attracting and retaining youth in farming is the major challenge ahead to many intellectuals and policymakers (Gangwar and Kameswari, 2016). Youths' socio-economic characteristics affect their opinions and attitudes and believed to have a significant influence on determining the types of activities and interactions toward their natural resources (Kavithaa and Rajkumar, 2017). Socio-economic factors directly or indirectly related to rural livelihood (Islam et al., 2015b) and often influence people's support for particular issues with respect to fishing occupation and degree of dependence (Shazia et al., 2020). Analysing the socio-economic correlates of attitude of youth of fishing communities towards fishing occupation in particular, can help us understand the attitudes and opinions towards adoption measures and policies. Undertaking these facts in consideration the present study has been conducted among youths of fishing communities in the fishing villages of district Bandipora of Kashmir.

\section{Materials and Methods}

Multistage random sampling technique (Ray and Mondol, 2004) was used to select the villages and the respondents. At first stage, four villages namely, Ashtingoo, Kulhama, Paribal and Lankreshpora were purposively 
selected because of the existence of fishing communities. At second stage, the simple random technique was used to select 30 respondents from each selected village thus, comprising 120 respondents. Data were collected from the sample respondents through interviews using a structured pretested interview schedule (Kumar, 2012). The youths were treated as the respondents for interview. The questions asked through interview schedule included data on socioeconomic characteristics of youth of fishing communities and their attitude towards fishing occupation. The socioeconomic variables of the youths included age, marital status, educational qualification, residential background, house type, family type, household earners, no. of dependents, household expenditure, investment on fishing inputs, active fishing days, income through fishing in summer, income through fishing in winter, marketing channels and opted alternate source of income and the variables were measured using "Socio-economic status scale" of Venkataramaiah (1990) after some modification. The coefficient of correlation ' $r$ ' (Snedecor and Cochran, 1967) was carried out to find out the relationship between socioeconomic characteristics and attitude of youth towards fishing occupation. The data were analyzed on MS Excel and Statistical Package for Social Sciences (SPSS) software and the results were displayed through table.

\section{Results and Discussion}

The socio-economic characteristics such as age $(\mathrm{r}=-0.757, \mathrm{p}=0.01)$, marital status $(\mathrm{r}=$ $0.376, \mathrm{p}=0.01)$, educational qualification $(\mathrm{r}=$ $-0.486, \mathrm{p}=0.01)$, family type $(\mathrm{r}=-0.787 \mathrm{p}=$ $0.01)$, household earners $(\mathrm{r}=-0.488, \mathrm{p}=0.01)$ and investment on fishing inputs $(\mathrm{r}=-0.584$, $\mathrm{p}=0.01)$ had exhibited negative and significant correlation with the attitude of youth towards fishing occupation while the variables like active fishing days $(\mathrm{r}=0.845$, $\mathrm{p}=0.01)$ and income through fishing in summer $(r=0.183, p=0.05)$ have shown positively significant correlation (Table 1). The other characteristics such as residential background $(r=0.132, p=0.05)$, house type $(\mathrm{r}=0.173, \mathrm{p}=0.05)$, number of dependents $(\mathrm{r}=$ $-0.004, p=0.05)$, household expenditure $(r=-$ $0.167, \mathrm{p}=0.05)$, income through fishing in winter $(\mathrm{r}=0.028, \mathrm{p}=0.05)$, marketing channels $(\mathrm{r}=-0.084, \mathrm{p}=0.05)$ and opted alternate source $(r=-0.023, p=0.05)$ had nonsignificant correlation with the attitude of youths towards fishing occupation (Table 1).

The negatively significant correlation between the age and attitude of youth towards fishing occupation might be because of the reason that young youth new to the profession do not find much profits at early stages while as old age group of youth being in this profession for long does not find any improvement or advancement in the sector and find the occupation less profitable with passing years which creates a negative impact on them regarding the occupation. Similar findings were reported by Shireesha et al., (2016). The negatively significant ' $r$ ' value between marital status and attitude of the respondents might be due to the pressure of shouldering family responsibilities by the single earner, notwithstanding the fishing occupation does not provide with enough income to satisfy the basic needs. Therefore, they shift to other less paid jobs and seldom carry out fishing activities. The finding was against the findings of Bello et al., (2015). The negatively significant correlation coefficient between educational qualification and attitude might be because of the reason that with acquiring education the youth aspire for gaining higher education and prosper in the same leaving fishing in the hands of aged people. The results were similar to the findings of Umunnakwe and Adedamola (2015). 
Table.1 Correlation between socio-economic profile and attitude of youth towards fishing as an occupation $(\mathrm{N}=120)$

\begin{tabular}{|l|l|c|c|c|}
\hline S. No. & Socio-economic variables & $\mathbf{r}$ & $\mathbf{p}$ & $\begin{array}{c}\text { Correlation } \\
\text { Coefficient }\end{array}$ \\
\hline $\mathbf{1}$ & Age & $-0.757^{* *}$ & 0.000 & Pearson \\
\hline $\mathbf{2}$ & Marital status & $-0.376^{* *}$ & 0.000 & Pearson \\
\hline $\mathbf{3}$ & Educational qualification & $-0.486^{* *}$ & 0.000 & Pearson \\
\hline $\mathbf{4}$ & Residential background & $0.132^{\mathrm{NS}}$ & 0.068 & Pearson \\
\hline $\mathbf{5}$ & House type & $0.173^{\mathrm{NS}}$ & 0.072 & Pearson \\
\hline $\mathbf{6}$ & Family type & $-0.787^{* *}$ & 0.000 & Pearson \\
\hline $\mathbf{7}$ & Household earners & $-0.488^{* *}$ & 0.000 & Pearson \\
\hline $\mathbf{8}$ & No. of dependents & $-0.004^{\mathrm{NS}}$ & 0.084 & Pearson \\
\hline $\mathbf{9}$ & Household expenditure & $-0.167^{\mathrm{NS}}$ & 0.058 & Pearson \\
\hline $\mathbf{1 0}$ & Investment on fishing inputs & $-0.584^{* *}$ & 0.000 & Pearson \\
\hline $\mathbf{1 1}$ & Active fishing days & $0.845^{* *}$ & 0.000 & Pearson \\
\hline $\mathbf{1 2}$ & Income through fishing in summer & $0.183^{*}$ & 0.000 & Pearson \\
\hline $\mathbf{1 3}$ & Income through fishing in winter & $0.028^{\mathrm{NS}}$ & 0.064 & Pearson \\
\hline $\mathbf{1 4}$ & Marketing channels & $-0.084^{\mathrm{NS}}$ & 0.074 & Pearson \\
\hline $\mathbf{1 5}$ & Opted alternate source of income & $-0.023^{\mathrm{NS}}$ & 0.066 & Pearson \\
\hline
\end{tabular}

**Significant at 0.01 level (2-tailed); *Significant at 0.05 level (2-tailed); NS= non-significant

The possible reason for the negative and significant coefficient of correlation between family type and attitude of respondents may be that since most of the respondents had nuclear families and therefore single earner or even two earners could not shoulder the whole family by doing fishing only and thus, affected their interest in fishing occupation negatively. The similar findings were found by Shireesha et al., (2016). The negatively significant correlation coefficient between household earners and attitude of respondents may be because the responsibilities of household needs are on the single individual and to meet the requirements by carrying out fishing only is not possible. Therefore, there arises a need to shift to some other sources to earn money and this creates disinterest in youth regarding fishing. The computed value of ' $r$ ' between investment on fishing inputs and attitude of respondents was found to be negatively significant which may be because the cost involved in making boats or gears is high. For making or repairing the old gears and crafts, enough wood is not provided at the government depots and therefore they have to get the wood from market which is available at high rates which they could not afford. Besides, they have no insurance for their gear and crafts.

The coefficient of correlation between active fishing days and attitude of youth was found to be positively significant which may be because of the reason that they observe good number of days on which fishing is carried out, although some days fetching less catch and thus more active days in a year have much influence on their attitude of youth towards fishing occupation. Conversely, the income through fishing in summer has shown positively significant coefficient of correlation with the attitude of youth of fishing communities towards fishing occupation. It is clear that for a unit increase in income through fishing in summer there is 
increase in favorable attitude of youth towards fishing. The possible reason for this relation may be that in summer season because of availability of good catch compared to other part of the year the youth get more income from fishing in this season by selling their catch and thus might think fishing as good occupation to follow. Since, the heterogeneity and inequalities of fishing communities created by private resource endowments of households is too inconsistent among all the people, the socio-economic factors like residential background, house type, number of dependents, household expenditure, income through fishing in winter, marketing channels and opted alternate source exerted non-significant correlation with the attitude of youth of fishing communities towards fishing occupation in Kashmir valley.

In conclusion the study revealed that the socio-economic characteristics of the youth showed positive as well as negative impacts on their attitude towards fishing occupation showing both favourable as well as unfavourable predisposition to participate in fishing occupational activities. Therefore, the impact of those variable needs to be taken into consideration during formation and implementation of developmental programmes that will help youth in developing positive attitude towards fishing and retain their interest in this profession. A positive attitude towards fishery occupation is a prerequisite for their engagement in the sector. In this regard, government should provide infrastructures and social amenities in the rural areas to encourage youths to live and work in the rural areas. Capacity building and skill development programmes needs to be strengthened among the rural youths to improve participation in fishery occupation. In line with this, youth's empowerment programmes should be intensified while also encouraging youth's organizations such as young farmers' clubs.

\section{Acknowledgements}

I extend my sincere thanks to all the youths of selected villages for their help and cooperation during data collection. I also wish to express my gratitude to the scientists of the Faculty for their support to develop this paper.

\section{References}

Aphunu, A. and Akpobasa, B. I. O. 2010. Assessment of rural youths' attitude towards agricultural production in Sapele local government area of Delta state. The Nigerian Academic Forum, 19(1): 1-6.

Bello, A. R. S., Allajabou, H. A. and Baig, M. B. 2015. Attitude of Rural Youth Towards Agriculture as an occupation: A case study from Sudan. International Journal of Development and Sustainability, 4(4): 415-424.

Brousmiche, K. L., Kant, J. D., Sabouret, N. and Prenot-Guinard, F. 2016. From beliefs to attitudes: Polias, a model of attitude dynamics based on cognitive modeling and field data. Journal of Artificial Societies and Social Simulation, 19(4): 2-13.

Eyinade, G. A. and Akharume, C. O. 2018. Farmers' Attitude towards Organic Farming Practices: A Concept of Sustainable Organic Farming Development in South Africa. Anthropologist, $\quad 32(1-3)$ : 102-106. DOI: $\quad 10.31901 / 24566802.2018 / 32.1$ 3.2004.

Gangwar, R. and Kameswari, V. L. V. 2016. Attitude of rural youth towards agriculture as a means of livelihood. Journal of Applied and Natural Science, 8(2): 879-882.

Islam, M. A., Masoodi, T. H., Gangoo, S. A., Sofi, P. A., Bhat, G. M., Wani, A. A., Gatoo, A. A., Singh, A. and Malik, A. R. 2015a. Perceptions, attitudes and 
preferences in agroforestry among rural societies of Kashmir, India. Journal of Applied and Natural Science, 7(2): 976-983. DOI: 10.31018/jans.v7i2.717

Islam, M.A., Rai, R., Quli, S.M.S. and Tramboo, M.S. 2015b. Socio-economic and demographic descriptions of ethnic people subsisting in forest resources of Jharkhand, India. Asian Journal of Bio Science, $\quad$ 10(1): 75-82. DOI: 10.15740/HAS/AJBS/10.1/75-82

Kavithaa, N. V. and Rajkumar, N. V. 2017. Factors contributing the attitude of farm women towards backyard poultry farming in erode district of Tamilnadu. International Journal of Science, Environment and Technology, 6(1): 573-579.

Kharmudai, A., Sumi, D. and Jyothi, S. S. P. 2018. Attitude of Tribal Farmers of Meghalaya towards ICT-Based Extension Services. Indian Journal of Hill Farming, 2018(Special Issue): 7175.

Kumar, R. 2012. Research methodology-A step by step guide for beginners. Dorling Kindersley (India) Pvt. Ltd., New Delhi, India.

Likert, R. A. 1932. A Technique for the Measurement of Attitudes. Arch. Psychol., New York, 140: 43- 55.

Movahedi, R., Latifi, S. and Sayyar, L. Z. 2013. The factors affecting agricultural students' attitude towards self employment and entrepreneurship. International Journal of Agriculture and Crop Sciences, 5(16): 1813-1819.

Nataraju, M. S., Lakshminarayan, M. T., Preethi and Lalitha, K. C. 2019. Attitude of Farmers towards Agriculture. International Journal of Current Microbiology and Applied Sciences, 8(01): 2729-2734. DOI: https://doi.org/10.20546/ijcmas.2019.8 01.288

Njeru, L. K., Gichimu, B. M., Lopokoiyit, M.
C. and Mwangi, J. G. 2015. Influence of Kenyan youth's perception towards Agriculture and Necessary Interventions; a review. Asian Journal of Agricultural Extension, Economics and Sociology, 5(1): 40-45.

Onima, V. T., Timbadia, C. K., Gulkari, K. D. and Bhuva, R. M. 2017. Attitude of farmers towards farming as an occupation. International Journal of Pure and Applied Bioscience, 5(5): 833-837.

Pakhmode, P. S., Rathod, M. K. and Bhagat, M. C. 2018. Attitude of rural youth towards farming as a major occupation. International Journal of Chemical Studies, 6(1): 1735-1738

Parmar VS, Sharma OP, Bhuva RM, Patel AI (2015). Relationship between personal and socio-economic characteristics of farmers and their attitude towards the use of Kisan Call Center. Trends in Biosciences, 8(3): 693-694.

Ray, G. L. and Mondol, S. 2004. Research Methods in Social Sciences and Extension Education, Kalyani Publishers, New Delhi, pp. 66-76.

Shazia, Tariq., Rizwana, Malik., Wani, G. B., Shah, T. H., Bhat, B. A., Aishi, Ishra., Rather, T. A. 2020. Effects of Psychological Factors on Entrepreneurial Activitamong Agricultural Students of Kashmir. International Journal of Current Microbiology and Applied Sciences, 9(1): $\quad 1668-1675 . \quad$ DOI: https://doi.org/10.20546/ijcmas.2020.9 01.184

Shireesha, K., Satyagopal, P. V., Lakshmi, T., Ravindrareddy, B. and Prasad, S. V. 2016. Correlates of profile and attitude of youth towards farming. International Journal of Agricultural Science and Research, 7(1): 43-52.

Snedecor, G. W. and Cochran, W. G. 1967. Statistical Methods. Iowa State 
University Press, Ames, Iowa-50010. Umunnakwe, V. C. and Adedamola, O. F. O. 2015. Socio-personal correlates of participation in livelihood activities among rural youth in Jabalpur district of Madhya Pradesh. International Journal of Agricultural Research Innovation and Technology, 5(1): 2835 .
Venkataramaiah, P. 1990. Development of socio-economic status scale, Ph.D. Thesis, Department of Agricultural Extension, University of Agriculture Sciences, Bangalore, Karnataka, India.

World Bank. 2001. The world youth forum report, Washington, D.C.

\section{How to cite this article:}

Ishrat Aishi, Rizwana Malik, Sajad H. Baba, Bilal A. Bhat, Shazia Tariq, TA. Rather and Islam, MA. 2020. Socio-economic Correlates of Attitude of Youth of Fishing Communities towards Fishing Occupation in Kashmir Valley. Int.J.Curr.Microbiol.App.Sci. 9(10): 172-178. doi: https://doi.org/10.20546/ijcmas.2020.910.022 